\title{
Sürdürülebilir Malzeme olan Urfa Taşının Tarihsel Süreçte ve Peyzaj Mimarlığında Kullanımları: Şanlıurfa Örneği
}

\author{
Hülya ÖZTÜRK TEL ${ }^{1 *}$ \\ ${ }^{1}$ Harran Üniversitesi, Şanlıurfa Teknik Bilimler Meslek Yüksekokulu, Mimari Restorasyon Bölümü, 63200, \\ ŞANLIURFA
}

\section{Öz}

Doğal taşlar; ilk çağlardan günümüze kadar kullanılan en eski yapı malzemesidir. Geçmiş zamanlarda yerel malzemeye erişimin kolay olması, geleneksel yöntemlerle işlenebilmesi ve uygulanabilir olması doğal malzemeyi tercih edilir kılmıştır. Taş doğaya zarar vermeyen, geri dönüşümlü, görsel güzelliği olan ve dayanıklı malzeme oluşundan dolayı yapıda, hem taşıyıcı hem de süsleme elemanı olarak kullanılmıştır. Günümüzde kullanımı artan doğal taşlar; inşaat, döşeme, heykelcilik, kent mobilyası, yol kaplaması, bordür taşı ve dekoratif süs eşyalarının yapımında halen kullanılmaktadır. Peyzaj mimarlığı çalışmalarında doğal taş kullanımı diğer malzemelere göre dayanıklı, estetik ve doğal malzeme olması açısından tercih edilmektedir. Bu araştırmada Şanlıurfa kentinde yörenin yerel malzemesi olan Urfa taşının özellikleri ve işlenmesi, tarihsel süreç içinde kullanımı, peyzaj mimarlığında kullanımları ve uygulama alanları incelenmiştir. Şanlıurfa geleneksel kent dokusu içinde Urfa taşı uygulamaları yerinde tespit edilmiş, kullanım amaçları irdelenmiş, diğer yapı malzemelerine oranla tercih sebepleri üzerinde durulmuştur. Çalışmanın sonucunda; Şanlıurfa kentinde yapılan peyzaj çalışmalarında Urfa taşının kullanımına ağırlık verilmesi ile tarihi kent merkezinde daha kimlikli mekanların oluşacağı, sosyo-ekonomik ve kültürel açıdan olumlu etkiler doğuracağı kanaatine varılmıştır.

Anahtar Kelimeler: Urfa taşı, peyzaj mimarlığı, Urfa taşının kullanımı, doğal malzeme, sürdürülebilirlik.

\section{Uses of Urfa Stone, a Sustainable Material, in Historical Process and Landscape Architecture: The Example of Şanlıurfa}

\begin{abstract}
Natural stones; It is the oldest building material used from the first ages to the present day. In the past, the ease of access to local materials, their ability to be processed and applied with traditional methods made natural materials preferable. Stone has been used both as a carrier and as an ornamental element in the building because it is a durable material that does not harm nature, is recyclable, has visual beauty and is durable. Natural stones, the use of which is increasing today; It is still used in construction, flooring, sculpture, urban furniture, road pavement, curbstone and decorative ornaments. The use of natural stone in landscape architecture works is preferred in terms of being durable, aesthetic and natural material compared to other materials. In this research, the characteristics and processing of Urfa stone, which is the local material of the region, in the city of Şanliurfa, its use in the historical process, its use in landscape architecture and its application areas were examined. Urfa stone applications within the traditional urban texture of Şanlıurfa have been determined in situ, their usage purposes have been examined, and the reasons for preference compared to other building materials have been emphasized. As a result of the study; It has been concluded that with the emphasis on the use of Urfa stone in the landscape works carried out in the city of Şanlıurfa, more identity places will be formed in the historical city center and it will have positive socioeconomic and cultural effects.
\end{abstract}

Keywords: Urfa stone, landscape architecture, use of Urfa stone, natural material, sustainability. 


\section{Giriş}

Geçmişten günümüze kadar yapı malzemesi olarak kullanılan doğal taş; sürdürülebilir, dayanıklı, doğal güzelliği ve çevreye zarar vermemesi gibi nedenlerden dolayı pek çok yapıda taşıyıcı ve süsleme ögesi olarak kullanılmıştır.

Özellikle Anadolu'da ortaya çıkan yeni uygarlıklar, önceki uygarlıkların kültürel mirasından yararlanarak, sanat ve mimaride ilerlemişler, her ne kadar savaşlar, doğal afetler ve istilalar bu uygarlıklara ve onların ortaya koydukları kültürel mirasa büyük zarar vermiş olsa da çok sayıda cami, kilise, kale, medrese, köprü, han, kervansaray, külliye gibi kültürel eserlerin günümüze kadar varlığını sürdürmesinde doğal taş malzemenin kullanılmasının önemli bir payı vardır ve özellikle mimaride taşın kullanımı oldukça fazladır (Alkan, 2015; Farrelly, 2011). Geçmiş zamanların teknik ve ekonomik durumu göz önünde bulundurulduğunda, doğal taşların doğada kolay bulunabilme, geleneksel ve basit yöntemlerle işlenebilme özelliği, basınca karşı mukavemeti gibi özelliklerinden dolayı bu malzemenin geçmişte ve günümüzde tercih edilmesini sağlamıştır. Anadolu' da kültürel değeri ulusal boyutta olan doğal taşlardan bazıları; Ahlat Taşı, Ankara Taşı, Lületaşı, Midyat taşı, Nevşehir taşı, Oltu taşı, Sille taşı, Urfa taşı, traverten ve mermerdir (Kazancı ve Gürbüz, 2014).

Günümüzde doğal taşların kesimi ve işlenmesi için kullanılan teknolojinin gelişmesi ile taşın kullanımını daha verimli ve çevreci olmuştur. Ayrıca taşın çıkarımı sırasında meydana gelen kırma taş veya taş tozu gibi ürünler dönüştürülerek inşaat ve diğer sektörlerde hammadde olarak kullanılabilmektedir. Bu durum malzemenin fiziksel ve çevresel açıdan sürdürülebilir olduğunu göstermektedir (Alptekin, 2021). Doğal taşlar yap1 ömrünü tamamlayıp bozulma yaşadıklarında bile başka bir yerde kullanılarak sürdürülebilirliği sağlanabilir. Diğer yap1 malzemelerinde yıllar geçtikçe bozulma olurken doğal taşlarda, kendine özgü bir görünüm kazanarak dayanıklılığı daha da artmaktadır. Doğal taşlarda, doğru bir restorasyon ile bozulmaların önüne geçilebilmektedir. Doğal taşlar uzun vadede ekonomik, ekolojik ve sürdürülebilir bir yapı malzemesidir. Sürdürülebilir malzeme olduğu için, ekosistemin dengesini bozmamaktadır. (Akgün vd., 2019; Aksoy, 2020).

Doğal taşların kullanımı çoğu meslek dalında kullanıldı̆̆ı gibi peyzaj mimarlığı çalışmalarında da önemli yer tutmaktadır. Bakım maliyetinin azlığı, uzun ömürlü olması, dayanıklı olması ve doğal görünüm katması açısında tercih edilmektedir (Reed, 2000). Doğal taşlardan peyzaj mimarlığında; hem yapı hemde kaplama malzemesi olarak (döşeme, duvar, bordür vb.) yararlanılmaktadır (Altınçekiç, 2001; Sağlık vd., 2012).

Urfa taşı 12000 yıldan beri Şanlıurfa ve çevresinde dini yapılarda, geleneksel konutlarda, askeri yapılarda, su yapılarında ve tapınaklarda kullanılarak günümüze kadar gelen, kentin çevresindeki taş ocaklarından çıkarılan doğal kireç taşı türüdür. Bu yöreye özgü olmasından dolayı Urfa taşı olarak anılmış ve kentin kimliğini yansıtmıştır. Urfa taşının uzun ömürlü olması, yeniden kullanılabilir, dönüştürülebilir olması fiziksel / çevresel sürdürülebilirlik açısından önemlidir.

Bu çalışmada; Urfa taşının özellikleri, tarihsel süreç içinde kullanımı, üretildikleri boyut ve formları, Şanlıurfa geleneksel kent dokusunda süsleme ögesi ve peyzaj mimarlığı çalışmalarında kullanımları incelenmiştir.

\section{Materyal ve Metot}

\subsection{Materyal}

Araştırma alanını, Şanlıurfa geleneksel kent dokusunda bulunan Urfa taşı ile inşa edilmiş cadde, yaya kaldırımları, orta refüj, meydan, kent parkları, geleneksel yapılar, cepheleri ve bahçe duvarları oluşturmaktadır (Şekil 1). 


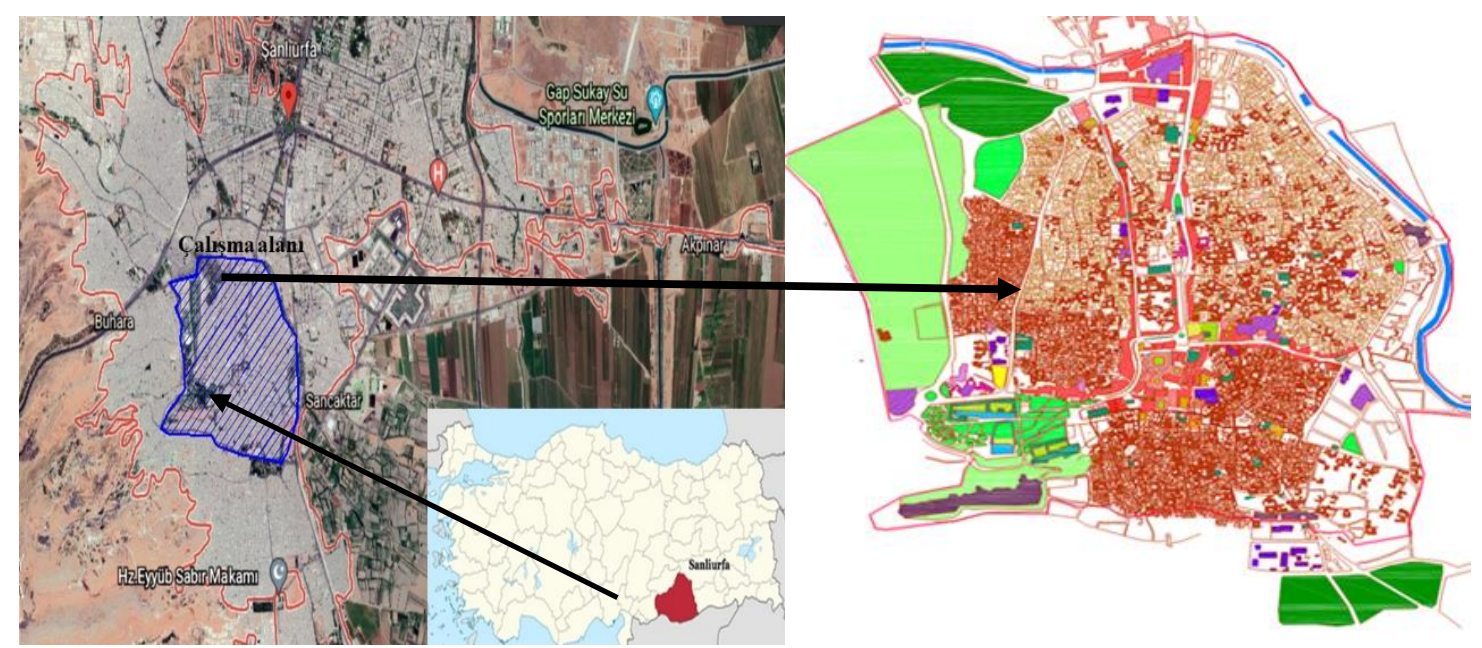

Şekil 1. Araştırma alanı, Şanlıurfa koruma amaçlı imar plan sınırı

\subsection{Metot}

Araştırmada Urfa taşı ve kullanımı ile ilgili Şanlıurfa ve Çevresindeki taş ocakları, Şanlıurfa Ticaret Odası ve taş ustaları ile yapılan görüşmelerden Urfa taşı ile ilgili veri toplanmış, Şanlıurfa geleneksel kent dokusunun mimarisinde yapılan incelemelerde Şanlıurfa geleneksel kent dokusu içinde Urfa taşı uygulamaları yerinde tespit edilerek fotoğrafları çekilmiştir. Ayrıca Urfa ve çevresindeki taş ocağı yetkilileri, taş ustaları ve sanat tarihçilerinden tespit ve gözlemlerde yardım alınmıştır. Urfa taşının özellikleri, tarihsel süreç içinde kullanımı, üretildikleri boyut ve formları, peyzaj mimarlı̆̆ında kullanımları incelenmiştir. Araştırma alanı içindeki Urfa taşının peyzaj mimarlığında kullanımları; bahçe duvarları ve kapıları, sert zeminler, merdivenler ve sınırlandırma elemanları, su ögeleri, plastik objeler, bilgilendirme levhaları ve çiçek kasaları başlıkları altında incelenmiştir. Bu çalışmada, ayrıca Urfa taşını uygulama teknikleri, ebatları ve kullanım nedenleri açıklanmıştır.

\section{Bulgular ve Tartışma}

\subsection{Urfa taşının özellikleri ve işlenmesi}

Şanlıurfa kenti ve çevresi doğal yapı malzemesi olan zengin kireçtaşı (Urfa taşı) kaynaklarına sahiptir. Şanlıurfa geleneksel kent dokusunun mimarisinde Urfa taşı hakimdir. Urfa taşının kolay işlenebilme kabiliyeti ve dayanıklılığı yüzyıllardır taşın mimariye hakim olmasını sağlamıştır. Urfa kenti ve çevresinde birçok taş ocağı olması ve 12.000 yıldır Urfa kireçtaşının kullanılıyor olması kentte taş işleme ustalığını canlı tutmuştur. Halk dilinde, yapılarda kullanılan kireçtaşına "Nahit Taşı" veya "Havara Daşı" isimleri de verilmektedir. Şanlıurfa'da büyük ölçekte ihracat yapan 5 taş ocağı bulunmaktadır. Bunun yanında Şanlıurfa ticaret odasının sistemine kayıtlı olmayan 35 küçük ölçekte Urfa taş ocağı yer almaktadır. Yıllık 31.680 ton işleme kapasitesi, 62.212 .500 ton görünür kireçtaşı rezervi bulunmaktadır (MTA, 2010; Anonim 2019a).

Urfa taşının tercih edilme nedenleri;

- Şanlıurfa kenti için geleneksel mimari ile uyumludur.

- Ocaktan çıktığında yumuşak, hava ile temasında sertleşip dayanıklılık kazanmaktadır. Dayanıklı ve uzun ömürlü malzeme olduğundan tekrar doğaya malzeme temini için müdahalede bulunulmayacak ve doğal kaynakların korunumu sağlanacaktır.

- Ocaktan çıkarıldığı süreçte işleme kolaylı̆̆ı nedeniyle taşın kolay bir şekilde bezenmesine imkan tanımaktadır. Disk testere yardımıyla ocaktan çıkarılan Urfa taşı tasarıma göre istenilen ebatta kesilerek kullanılması mümkündür (Şekil 2).

- Urfa kenti yakınlarındaki taş ocaklarından çıkarıldığından nakliye için fazla enerji maliyeti gerekmeyecek, Şanlıurfa'nın yerel kaynağı kullanılmış olacaktır.

- Isı yalıtımı sağlaması, çevreye zarar vermeyen sürdürülebilir malzeme olması ve maliyetinin düşük olması önemli avantajları arasındadır (Turgut vd., 2006). 


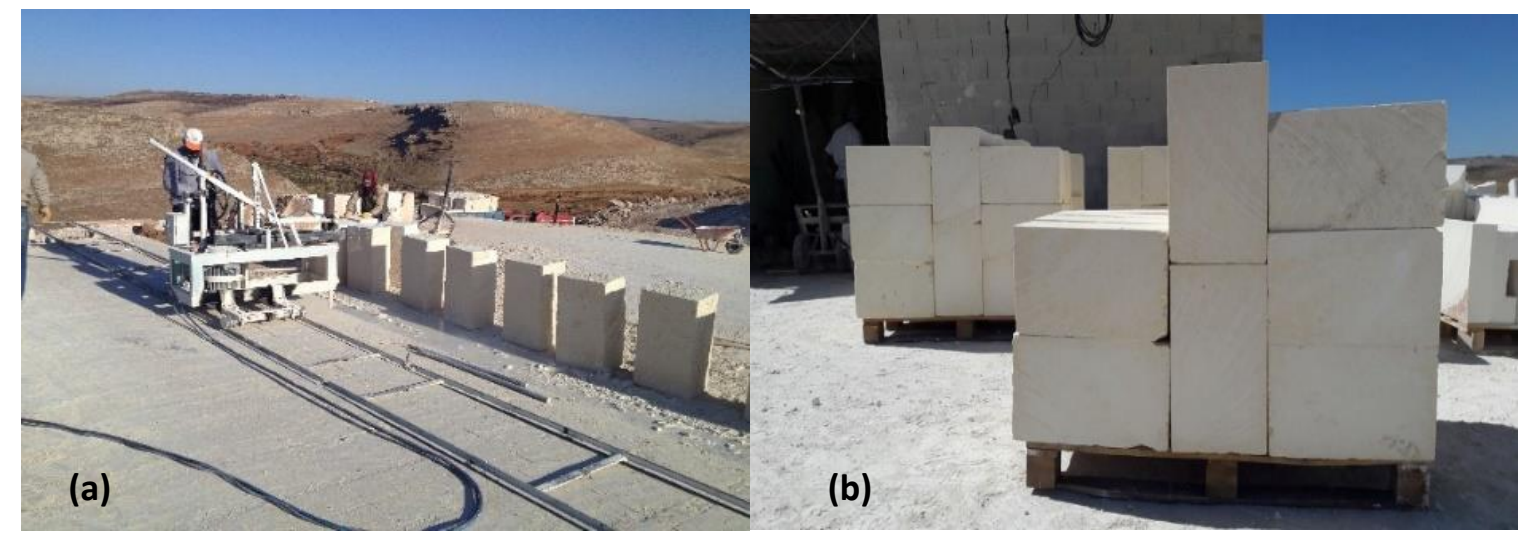

Şekil 2. (a) Ocaklardan urfa taşının disk testere yardımı ile kesimi; (b) Urfa taşının ebatlanmış şekli

Özellikle taşın kolay işlenebilme özelliğinden dolayı el işçiliği ile işlenmesi mümkün olduğundan taş ustaları; ustaçırak ilişkisi yoluyla taş işlemeciliğini geliştirmişlerdir. Ancak günümüzde bu sanatın zorluğu ve gerekli kurslarının açılmamasından dolayı kaybolma tehlikesi ile karşı karşıyadır. Günümüzde taş işlemeciliği el işlemeciliğinin yanında modern bilgisayar kontrollü makinelerde de (CNC, Computer numerical control) yapılabilmektedir (Şekil 3).


Şekil 3. (a) Urfa taşının elle işlenmesi; (b)Urfa taşının bilgisayar kontrollü makine (CNC) ile işlenmesi

\subsection{Tarihsel Süreç Içinde Kullanımı}

Urfa taşı M.Ö. 12000 yıl öncesinden günümüze kadar Şanlıurfa kentinde; Göbeklitepe, Harran Ulu Camii, Urfa Kalesi ve geleneksel Urfa konutları gibi çoğu yapıda; yapı ve süsleme malzemesi olarak kullanılmıştır (Ağan, 2016).

Göbeklitepe' de urfa taşından yapılan yaklaşık 60 tonluk T şeklindeki sütunlarda; yabani sığır, akrep, tilki, yılan, aslan, yaban eşeği, yaban ördeği ve yabani bitki kabartmaları yer almaktadır (Şekil 4, Şekil 5a) (Kürkçüoğlu, 2016).

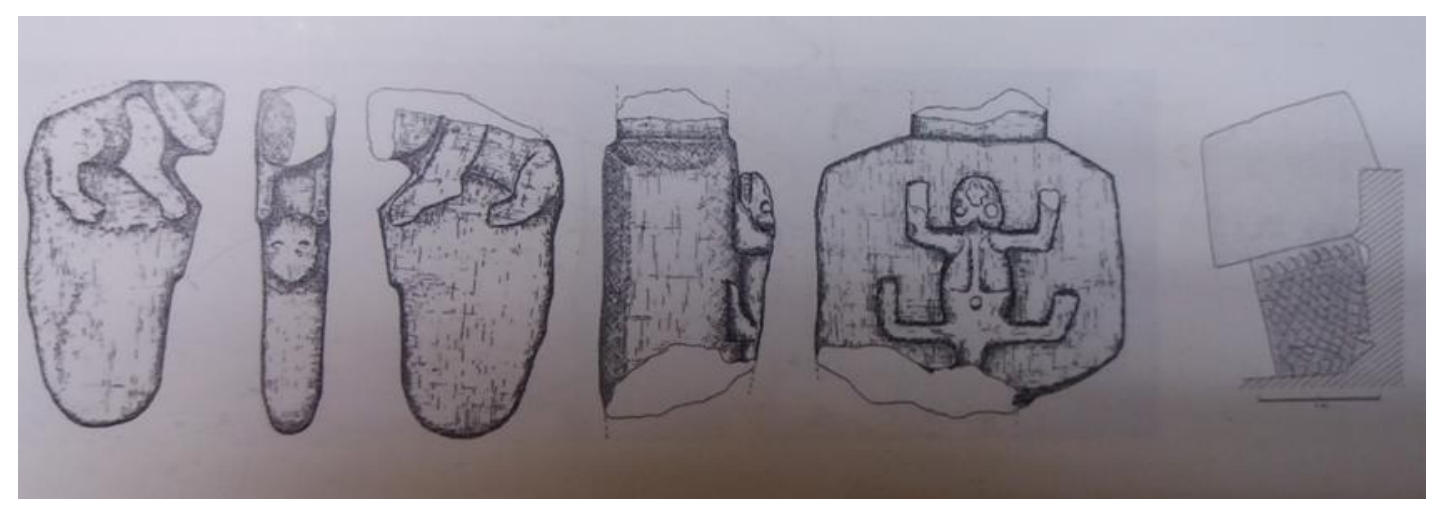

Şekil 4. Göbeklitepe taş kabartmaları (Kürkçüoğlu, 2016). 
Harran Ulu Cami'de taştan yapılmış sütun başlıkları dikkat çekicidir. Harran Höyüğü’nün kuzeydoğu eteğinde yer alan Harran Ulu Cami, 744-750 yıllarında Emevi Hükümdarı II. Mervan tarafından yaptırılmıştır Emeviler dönemine ait sütun başlıkları, rumili kıvrımların bulunduğu derin oyulmuş kompozisyonlarla süslenmiş olup, taş işleme geleneğinin çok eskilere dayandığı görülmektedir (Anonim, 2019b) (Şekil 5b).

M. S. 2. yüzyılda önemli bir kült (tapınma) merkezi olarak bilinen Soğmatar harabeleri, Şuayb şehri kesme urfa taşından yapılmış antik kentlerdir (Kürkçüoğlu ve Erkol, 2013; Albayrak 2015).
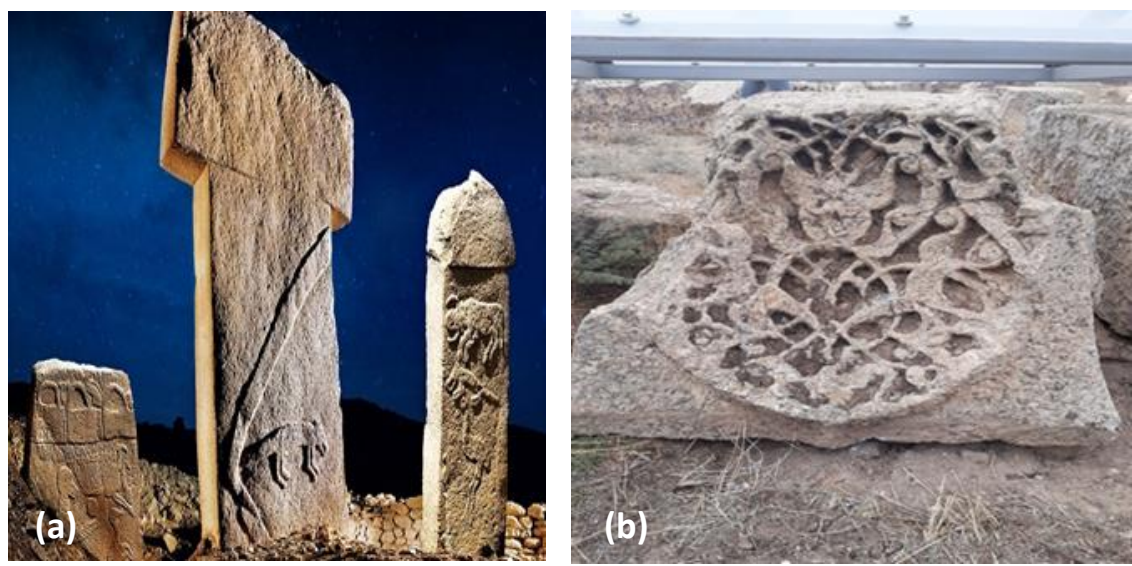

Şekil 5. (a) Göbeklitepe 'T' formlu dikilitaşlar (Steller) (Anonim 2021); (b)Harran Ulu Camii sütun başları.

Yüzyıllar önce başlayan taş işleme ustalığı Urfa geleneksel kent merkezindeki yapılarda kullanılmasıyla devam edilmiştir. Pagan, Roma, Haçlı etkileri, İslam ve Osmanlı mimarisinin örneklerinin bulunduğu Şanlıurfa mimarisinde Urfa taşı, yapı malzemesi ve süsleme ögesi olarak kullanılmıştır. Şanlıurfa geleneksel yapılarda bulunan taş süslemeler; geometrik ve bitkisel motifleri ile zenginlik sunmaktadır. İslami dönemde insan ve hayvan figürlerinin yer aldığı heykeller, İslamiyette hoş karşılanmayınca geometrik ve bitkisel motifler kullanılmış, geleneksel kent dokusundaki cami, han, hamam gibi anıtsal eserlerin yanında geleneksel konut mimarisinde de urfa taşının geometrik ve bitkisel motiflerle bezenerek kullanıldığı görülmektedir. Genellikle taç kapıları ve havalandırma takalarında bitkisel süslemelere rastlanmaktadır (Şekil 6 a,b). Şanlıurfa'daki dini yapılarda urfa taşının süslemeye daha az yer verilerek daha sade kullanıldığı söylenebilir (Şekil $6 \mathrm{c}$ ).


Şekil 6. (a) Hacıbanlar Evi Mutfak Müzesi havalandırma takası; (b) Harran Üniversitesi Kültür Evi (Akçarlar Evi) taç kapı; (c) Mevlid-i Halil (Dergâh) Cami.

\subsection{Urfa Taşının Peyzaj Mimarlığında Kullanım Alanları}

Şanlıurfa geleneksel kent dokusunda yerel malzeme olan Urfa taşının peyzaj mimarlığı çalışmalarında da kullanıldı̆̆ı saptanmıştır.

Urfa taşının peyzaj mimarlığı çalışmalarında kullanımları yer ve amaçlarına göre ayrıntılı bir şekilde; bahçe duvarları ve kapıları, sert zeminler, merdivenler ve sınırlandırma elemanları, su ögeleri, plastik objeler, bilgilendirme levhaları ve çiçek kasaları başlıkları altında incelenmiştir. 


\subsubsection{Bahçe Duvarları ve Kapıları}

Duvarlar, bahçenin en önemli sınır ögeleridir. Bahçeyi sınırlarken mekan etkisi de oluşturarak gürültü, rüzgar ve toza karşı korurlar. Bahçe kapıları da girişleri anlamlı kılan ögelerdir. Şanlıurfa geleneksel kent dokusunda bahçe giriş kapıları anıtsal taç kapı niteliğinde Urfa taşından geometrik ve bitkisel süsleme yapılarak kullanılmıştır (Şekil 7).
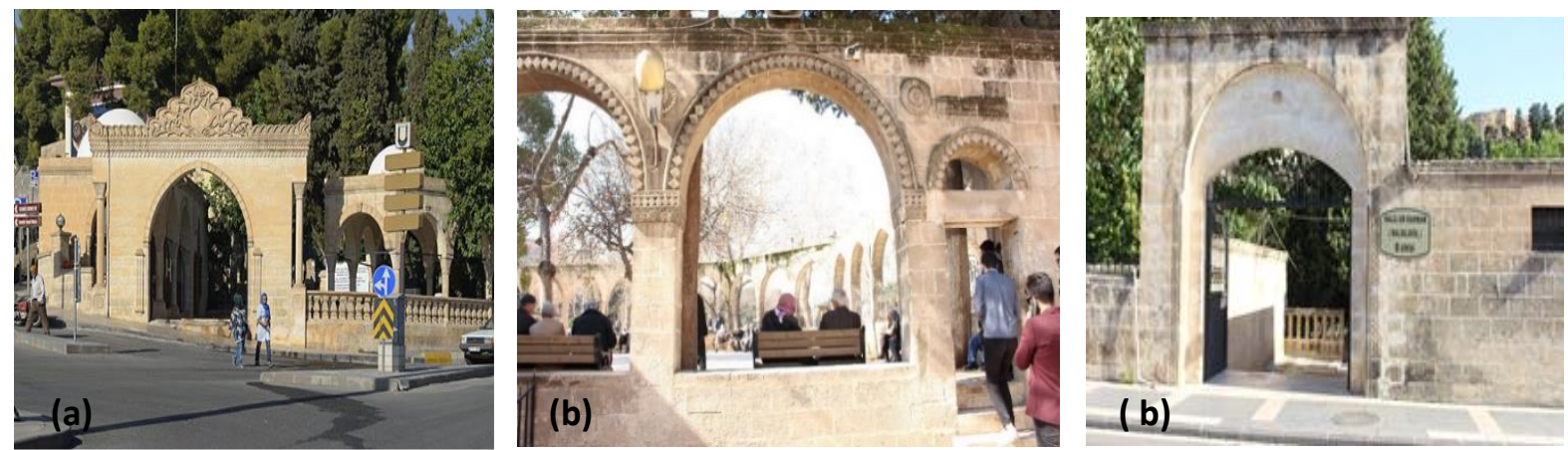

Şekil 7. (a) Şanlıurfa Bediüzzaman Mezarlığı giriş kapısı; (b) Balıklıgöl giriş kapıları.

Taş duvarlar taşıdıkları yük ve mekana göre; 45, 50, 60 veya $70 \mathrm{~cm}$ kalınlıkta yapılabilirler. Urfa taş malzeme ile kesme blok taş duvarlar yapılabileceği gibi kesme blok kaplama duvarda yapılabilir. Kesme blok Urfa taşı duvar, yapıştırma harcı ile malzemenin birbirlerine kenetlenmesi sağlanarak oluşturulan duvar tipi; en yaygın kullanılan tiptir. Uygun ebatta kesilen Urfa taşları kenarlardan içeri doğru oluklar açılarak içerisine derz dolgusu doldurularak taşların kenetlenmesi sağlanır (Şekil 8a). Kesme blok kaplama taş duvar ise kalınlığı en az 5 cm olacak şekilde kesilen blok urfa taşları ile kaplama yapılması mümkündür. Üst üste gelen taşlar şaşırtılarak yerleştirilir ve derzlerin üst üste binmesi engellenmelidir (Şekil 8b). Duvarlarda kullanılacak Urfa taşında; homojen, damarsız ve çatlaksız olmasına özen gösterilmeli, laboratuvar testinden geçmiş dayanıklı Urfa taşları tercih edilmelidir.


Şekil 8. (a) Urfa taşına oluk açılarak kenetlenmesi; (b) Urfa taşı kaplama

\subsubsection{Sert Zeminler}

Yaya yolu, kaldırım gibi sert zeminler için en dayanıklı, doğal ve estetik zemin kaplamaları doğal taşlardan oluşmaktadır. Yaya yolları, havuz kenarı ve teraslar gibi yükün çok binmediği mekanlarda Urfa taşı kullanılabilmektedir. Urfa taş malzeme kesilmiş ve işlenmiş olarak, harçla $40 * 25 * 5 \mathrm{~cm}$ ebatlarında kullanılabileceği gibi $40 * 40 * 5 \mathrm{~cm}$ ebatlarında da üretilerek kullanılabilir. Ancak ağır taşıtların geçebildiği mekanlarda kullanıldığında Urfa taşında, çatlama ve kırılmalar meydana geldiğinden dolayı kullanımı elverişli değildir. Urfa taşı düzgün yüzeyli kaplama malzemesi olarak tercih edilmesi daha uygundur. Urfa taşı, açık sarımtırak renge sahip olduğundan güneş 1şı̆̆ını yansıtır ve bulunduğu mekânın daha serin olmasını ve ferah görünmesini sağlar. Özellikle sıcaklığın fazla olduğu mekanlar için kullanımı idealdir.

Sert zeminlere uygulanmasında en az $10 \mathrm{~cm}$ 'lik temel beton olması gereklidir. Temel betonun üzerine 1slak bir harç koyularak Urfa taşı 0,5-1 cm arası derz bırakılarak döşenir. Taşların diziliminde \% 2' lik bir eğim bırakılmasına özen göstererek su birikimleri engellenir. Derzler harçla doldurularak yapımı tamamlanır (Şekil 9). 




(a)
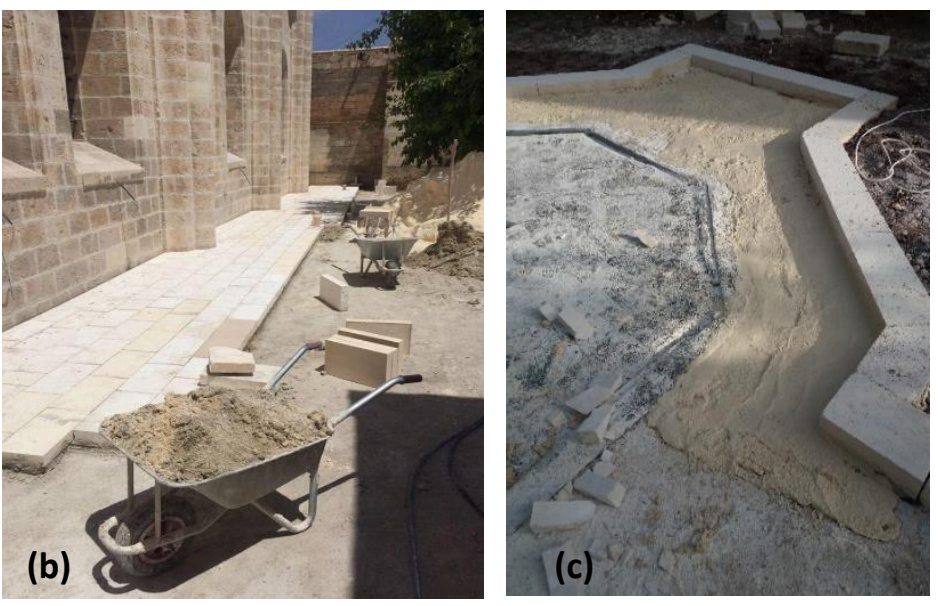

Şekil 9. (a) Urfa taşı bordür; (b,c) Urfa taşı kaplama (Anonim, 2020)

\subsubsection{Merdivenler ve Sınırlandırma Elemanları}

Merdivenler, dış çevrede kullanılan, farklı malzeme ve kullanım amacına göre tasarlanıp çeşitli boylarda inşa edilen peyzaj öğeleridir. Eğimin \%10 'un üzerinde olduğu alanlarda tercih edilir. Eğimin \% 10 'un altında olduğu alanlarda kullanımı isteğe bağlıdır (Huber, 2006).

Urfa taşından merdivenler, uygulama olarak çoğunlukla kaba yonu kesme taş olarak uygulanır (Şekil 10a). Basamaklar birbirlerine uç kısımlarından oturtularak, altına serilen yapıştırma harcı ile bağlantıları sağlanır. Urfa taşının $5 \mathrm{~cm}$ kalınlığında kaplama malzemesi olarak üretilerek betonun kaplanması şeklinde uygulamalarda mevcuttur. Merdivenlerde su drenajının sağlanması için \% 1'lik eğim yapılmalıdır (Özdemir, 2005).

Sınırlandırma elemanları; mekanı sınırlandırırken insana bulunduğu mekanda daha güvenli, korunaklı ve mahremiyetli bir ortam oluşturur. Bulunduğu mekanın tasarımı ve malzemesi ile uyumlu olması halinde ortama daha estetik bir hava katarlar. Örneğin Urfa taşı ile yapılan bir zemin kaplaması, Urfa taşı ile yapılan bir sınırlandırıcı ile devam ettirilirse mekan daha uyumlu ve yapıcı olmaktadır. Urfa taşı ile yapılan sınırlandırma elemanı uygulamalarında el ya da bilgisayar kontrollü makine $(\mathrm{CNC})$ ile farklı desenlerde işlenmiş kaba yonu taşlar yapıştırma harcı ile eklenip, demir malzeme ile kenet yapılarak birleştirilmektedir (Şekil 10b). Geometrik motiflere ağırlık verilmekte olup, Selahattin Eyyübi Camii avlusundaki sınırlandırma elemanında tam ve yarım dairelerin kesişimi sonucu oluşan motif kullanılmaktadır (Şekil 10c).


Şekil 10. (a)Urfa Ulu camii bahçesi urfa taşı merdiven; (b) Balıklıgöl Ayn Zeliha Gölü çevresi sınırlandırma elemanı; (c) Selahattin Eyyübi Camii avlusu sınırlandırma elemanı.

\subsubsection{Su Ögeleri}

Su ile yapılan tasarımlar ortama hareketlilik, görsellik ve işitsellik katar. Mekan konforu artırır, ortama serinleme hissi vererek, insanı psikolojik olarak rahatlatır. 
Çeşmeler, su kuyuları, fıskiyeler, şadırvanlar, süs havuzları, su yolları ve kanalları kentsel mekâna estetik ve hareketlilik katan elemanlardır. Su ögeleri, yüzyıllardır tasarımlarda kullanılmıştır. Günümüzde meydan tasarımlarında, konut avlularında ve dini yapıların bahçelerinde su ögeleri görülmektedir (Güner, 2015). Urfa geleneksel kent dokusunda Urfa taşından yapılan su ögeleri sıklıkla kullanılmaktadır. Urfa taşının kullanıldığı su ögeleri;

- Su yolları ve kanallar

- Süs havuzları ve fiskiyeler

- Şadırvanlar, çeşmeler, su kuyuları olarak değerlendirilmiştir.

Su yolları ve kanallar; kent içinde su yolları ve kanallarının sirkülâsyonu, ortamın mikroklimatik konforuna katkı sağlamaktadır. Şanlıurfa geleneksel kent dokusu içerisinde Balıklıgöl'den Hasan Padişah Cami'ne doğru yapılan su yolu ortama mikroklimatik konfor sağlarken doğal ve huzurlu bir ortamda oluşturmaktadır (Şekil 11a,b). Geleneksel konutların avlularında da çiçekliği sarmalayan Urfa taşından yapılan su yolları da bulunmaktadır (Şekil 11c). Yapılan bu uygulamalar, Urfa taşı ile su yolu ve kanallarının tasarlanabileceğini göstermektedir.
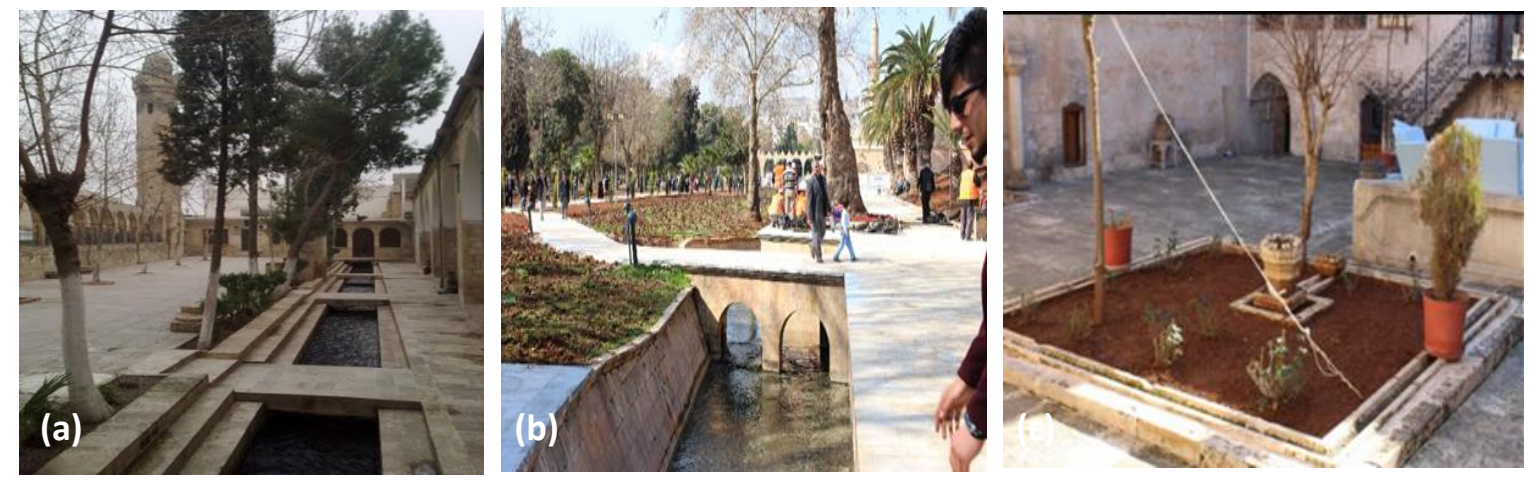

Şekil 11. (a) Hasan Padişah Camii avlusu su kanalı, (b) Balıklıgöl su kanalı; (c) Hacı Hafız Ahmet Efendi Evi Su Yolu.

Şanlıurfa geleneksel konutların eyvan ve avlularından geçen su yolları üzerinde bulunan, suyun akışı sırasında ses çıkartarak bir melodi oluşturan, ortama serinlik veren yılan şeklinde spiral oyulmuş taşlara su yolu (çöpür taşı) denilmektedir. Şanlıurfa geleneksel konutu olan Akçarlar evi şimdiki kullanımı ile Harran Üniversitesi Kültür Evi'nin eyvanında su yolu olan çöpür taşı ortama serinlik vermektedir (Şekil 12). İstenilen ebatta el oymacılığ ve bilgisayar kontrollü makine (CNC) ile yapılabilmektedir.

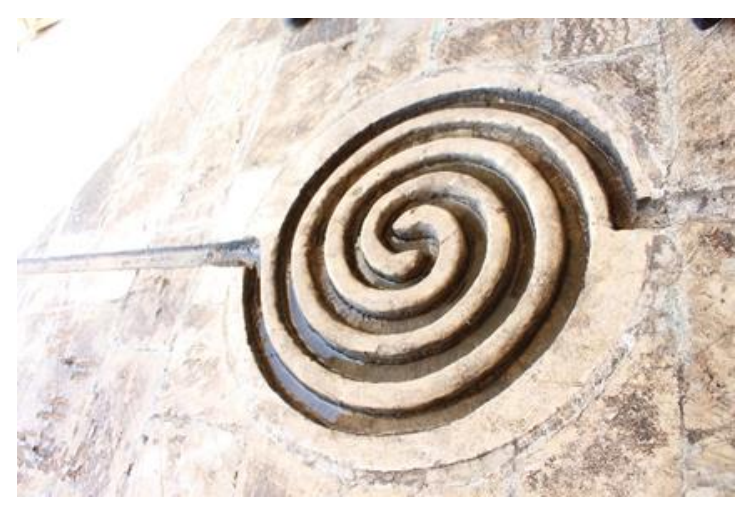

Şekil 12. Harran Üniversitesi Kültür Evi (Akçarlar Evi) eyvanında bulunan su yolu (çöpür taşı)

Süs Havuzları ve Fıskiyeler; ortama serinlik ve huzur katan peyzaj ögeleridir. Süs havuzunun tümü uygun ebatta kesilen Urfa taşı ile yapılabileceği gibi, beton olarak yapılan süs havuzu 5 cm'lik Urfa taşı ile kaplanması da mümkündür. Fiskiyeler, durgun su yüzeyini harekete geçiren, ortama serinlik hissi veren bahçede güçlü bir etki yaratan ögelerdir. Şanlıurfa geleneksel konutların avlularında çoğunlukla kullanılmaktadır (Şekil 13). Urfa taşından el işçiliği ile yapılabileceği gibi bilgisayar kontrollü makinelerde (CNC) ile yapılabilmektedir. 

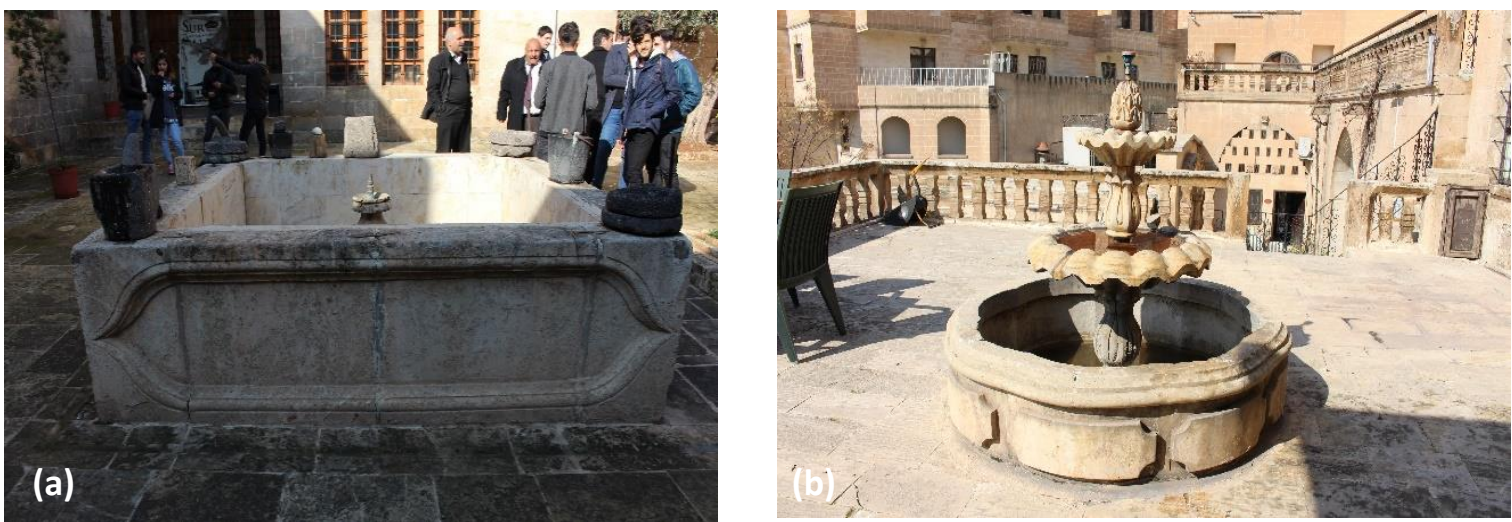

Şekil 13. (a)Hafız Ahmet efendi evi süs havuzu; (b) Harran Üniversitesi Kültür Evi (Akçarlar Evi süs havuzu ve fiskiyesi

Şadırvanlar, Çeşmeler, Su kuyuları; şadırvanlar, cami avlularında abdest almak için yapılan fonksiyonel olduğu kadar dekoratif amaçla da yapılan çeşmelerdir. Şanlıurfa geleneksel kent dokusunda bulunan şadırvanların; su haznesi ve sütunlu ayaklarının Urfa taşından kaplama veya istenilen ebatta kesme taş olarak inşa edilmiştir (Şekil 14)
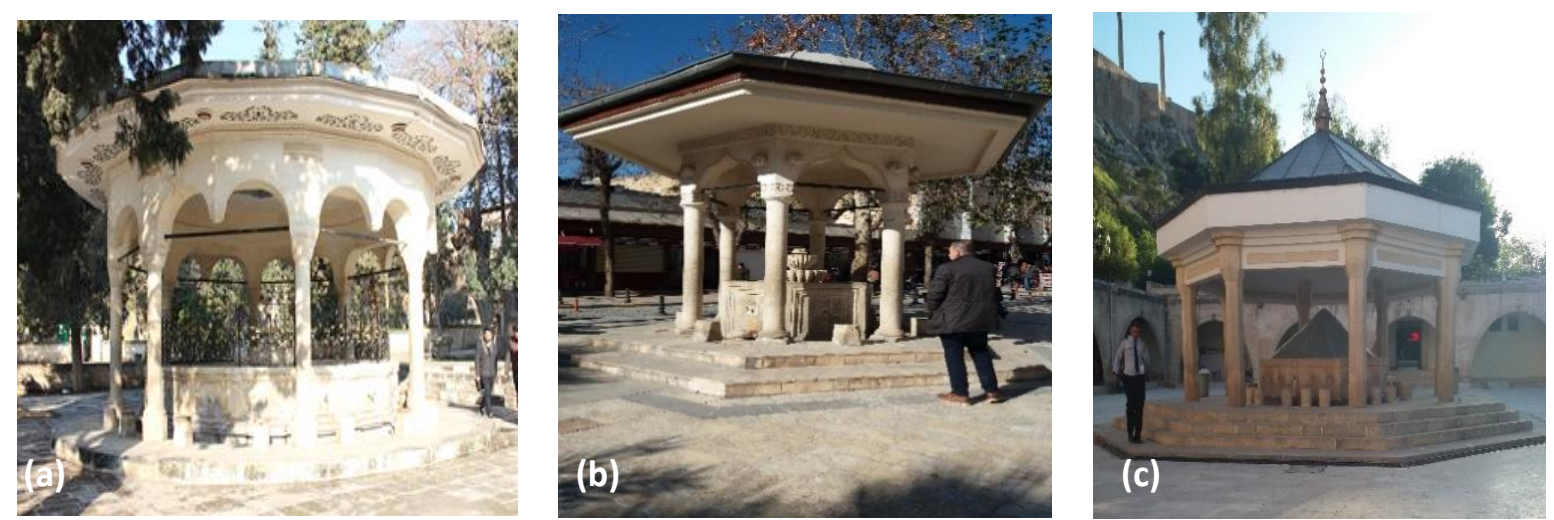

Şekil 14. (a) Şanlıurfa Ulu Camii Şadırvanı, (b)Hüseyin Paşa Camii Şadırvanı, c)Mevlid-i Halil (Dergah) Cami batı avlusu şadırvanı

Çeşmeler; estetik ve fonksiyonel amaçla kullanılan insanların su ihtiyacını karşılayan elemanlardır. Geleneksel Türk kentlerinde, su ögelerinden özellikle çeşmeler önemli bir yere sahip olup, yazları uzun geçen yerlerde tercih edilmektedir (Şişman ve Yetim, 2004). Çeşmeler; meydan çeşmesi, duvar çeşmesi ve köşe çeşmesi olmak üzere üç gruba ayrılmaktadır. Urfa kentinde üç tip çeşmeyi de görmek mümkündür.

Türk kültüründe farklı ve özgün bir yere sahip olan çeşme kültürünün Şanlıurfa kentinde Urfa taşından süslemeli bir şekilde yapıldığı görülmektedir. Urfa taşından süslemeli olarak yapılan çeşmeler, kenti daha kimlikli kılmaktadır. Fevziye Yüksel Büyükhatipoğlu Çeşmesi, Sarayönü Caddesi üzerinde yer alan Urfa taşından el işçiliği ile günümüzde yapılan bir meydan çeşmesidir. 1891 yılında 58 meydanında yapılan Şeyh Saffet Çeşmesi; Urfa taşı malzemeden kenarlarında bitkisel açık motiflerin kullanıldığı duvar çeşmesidir (Şekil 15 a,b).

Kuyular; Urfa geleneksel konutlarında su sağlamak amacıyla Urfa taşından yapılan mimari ögelerdir (Şekil 15c). 

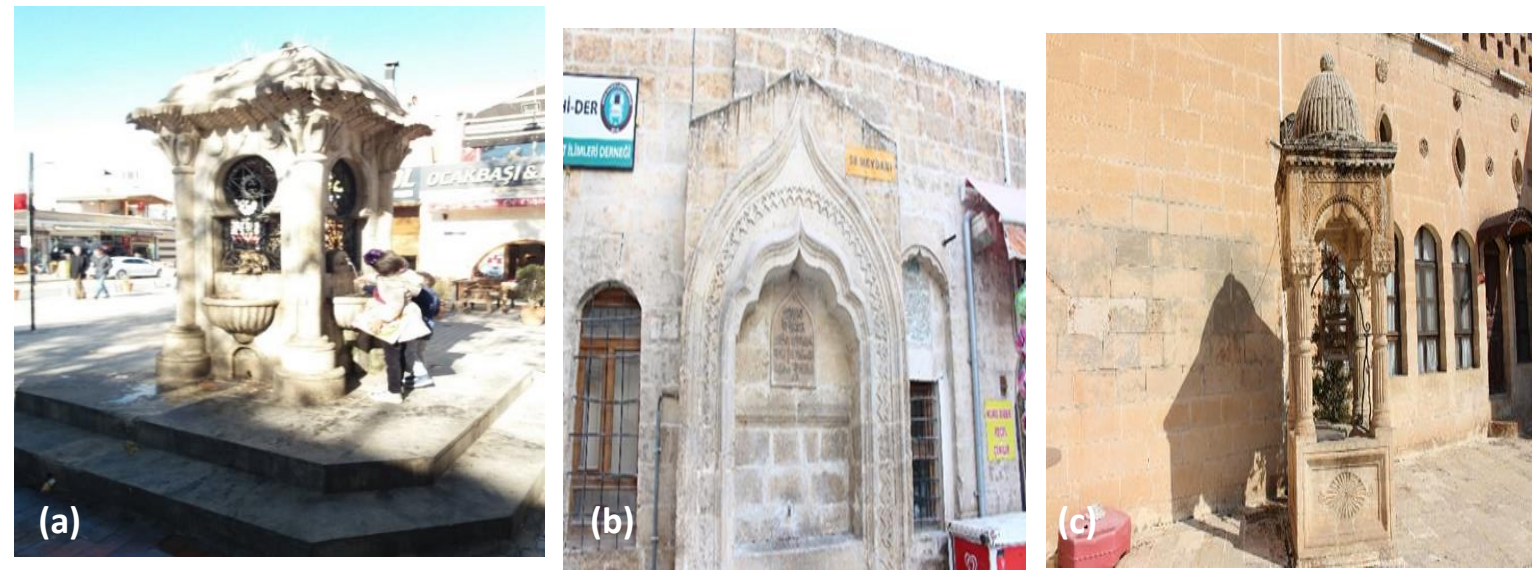

Şekil 15 (a) Fevziye Yüksel Büyükhatipoğlu çeşmesi; (b)Şeyh Saffet Çeşmesi; (c) Harran Üniversitesi Kültür Evi (Akçarlar Evi) su kuyusu

\subsubsection{Plastik Objeler}

Plastik objeler, peyzajın estetik değerini arttıran, tasarımı daha etkili kılan kent mobilyalarıdır. Bulunduğu çevreye odaklanılmasını sağlarken, çevreyi daha kimlikli yapar. Heykel ve plastiklerin kullanımında, yer seçimi, yörenin iklimi, kullanılan malzeme, dayanıklılık gibi unsurların göz önünde tutulması gerekmektedir.

Peyzaj mimarlığı çalışmalarında kullanılan plastik objeler, peyzajın görsel değerini artırırken, renk, form, biçim ve ölçü özellikleri ile tasarımı daha etkili ve algılanabilir kılan donatı elemanlarıdır (Erdönmez ve Çetingöz, 2019).

Kent meydanlarında, park ve bahçelerde kullanılan plastik objeler, kent girişlerinde ve dikkat çekilmesi istenen yerlerde; kent peyzajının görsel değerini arttırır ve algılanabilir kılmaktadır (Güremen, 2011). Anlatım özelliklerinin yanında, zevk verici ve estetik özelliklere sahip olup, bulundukları mekâna anlam ve kimlik kazandıran donatılardır (Uzun, 1990). Bunlar saat kuleleri, abideler, taştan yapılan plastik objeler olarak değerlendirilebilir. Bunlardan Şanlıurfa geleneksel kent dokusu içinde Urfa taşının elde işlenmesi ile saat kulesi ve hayvan figürleri Samsat Kapı Meydanı'na kimlik kazandırmıştır (Şekil 16). Bu objelerin yeni teknolojilerle kolay bir şekilde bilgisayar kontrollü makinelerde $(\mathrm{CNC})$ yapılması mümkündür.
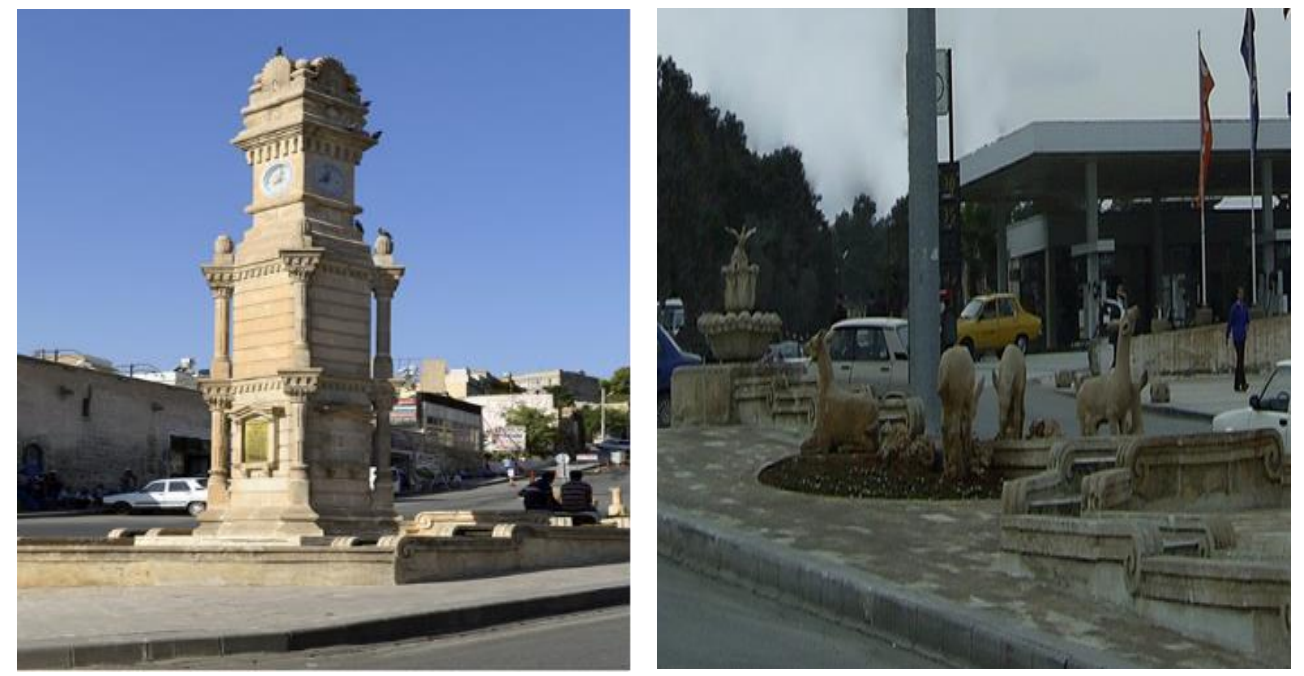

Şekil 16. Samsat Kapı Meydanı Saat kulesi ve hayvan objeleri

\subsubsection{Bilgilendirme Levhaları ve Çiçek Kasaları}

Kentsel donatı elemanlarından bilgilendirme levhaları ve çiçek kasaları önemli bir yere sahiptir. Balıklıgöl kent platosunda, kent kimliği ile uyumlu bilgilendirme levhaları ve çiçek kasaları tespit edilmiştir. Tespit edilen kent mobilyalarının bitkisel motiflerle süslenerek estetik hale getirildiği görülmüştür (Şekil 17). Bu kentsel donatı 
elemanlarının istenilen ebatta kesilebilen Urfa taşının, el işçiliği ve bilgisayar kontrollü makinelerde (CNC) kullanılarak yapımı mümkündür.
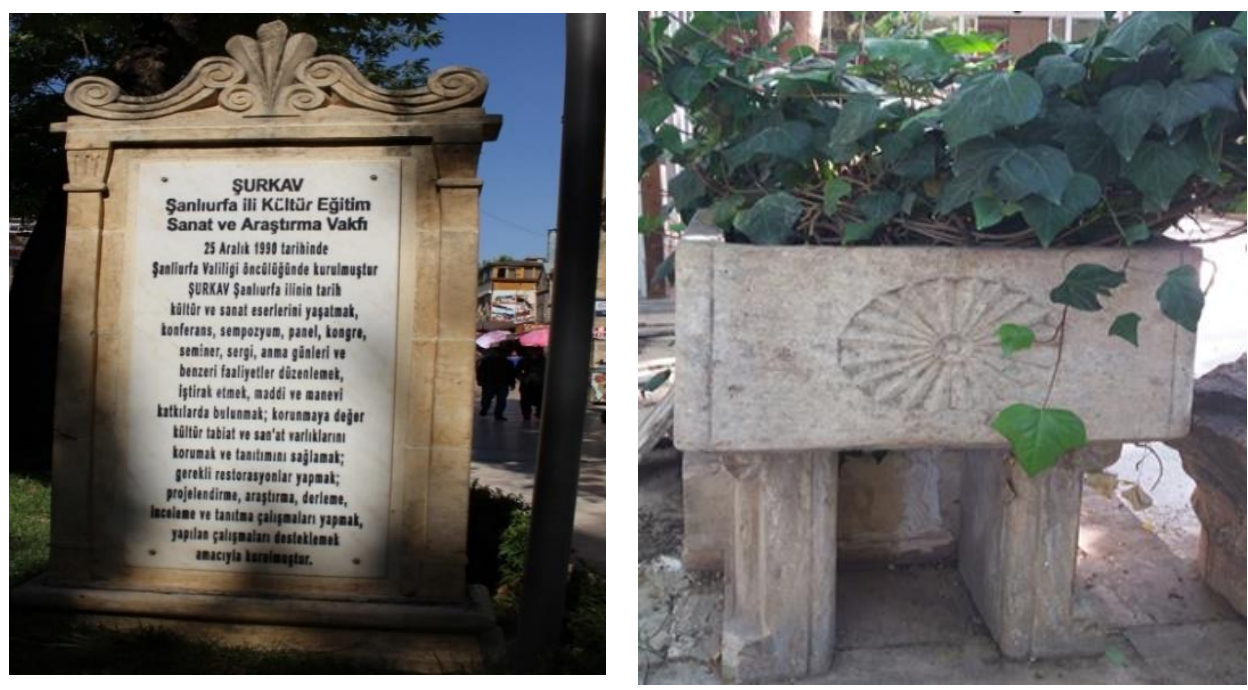

Şekil 17. Balıklıgöl kent platosunda bilgilendirme levhası ve çiçek kasası

\section{Sonuç ve Öneriler}

Doğal taşlar; yapay malzemelere oranla farklı desen ve renk seçenekleri sunması, iklim koşullarına dayanıklılığı, işlenebilirliliği, uzun ömürlü ve dayanıklı olması, ekonomik ve bakım masraflarının az olması gibi özelliklerle ön plana çıkmaktadır (Neufert, 1979).

Şanlıurfa kenti, Urfa taşı açısından oldukça zengin rezervlere sahiptir. Bu zenginliğin mutlaka değerlendirilmesi gerekmektedir. Şanlıurfa kentinde yapılan peyzaj çalışmalarında, Urfa taşının kullanımı ile özellikle tarihi kent merkezinde daha kimlikli mekanların oluşacağı, sosyo-ekonomik ve kültürel açıdan olumlu sonuçlar doğuracağı tespit edilmiştir. Urfa taşının peyzaj düzenlemelerinde kullanımı, tasarımların görsel kalitesini artırmakta, insanı doğaya yaklaştırmaktadır. Urfa taşı, dayanıklı, ekolojik, işlevsel, estetik açıdan göz alıcı ve sağlam bir malzeme türüdür. Ancak kullanılacak yer ve amacının da doğru saptanması gerekmektedir.

Şanlıurfa geleneksel kent dokusunda; yapılarda, bahçe duvarları ve kapıları, yürüyüş yolları, sert zeminler ve bordürler, merdivenler ve parmaklıklar, su ögeleri, heykeller ve plastik objelerde Urfa taşı tercih edildiği görülmüştür. Ancak günümüzde Şanlıurfa'da yerel yönetimler; peyzaj düzenlemelerinde Urfa taşını arzu edilen seviyede kullanmayıp bunun yerine yöreye ait olmayan yapay malzemeleri kullanmaktadırlar. Bunun nedeni tasarımcı ve kullanıcıların Urfa taşının üretildiği yer, üretim boyutları, kullanım alanları, tekniğine uygun uygulama şekilleri ve uygulama sonrası sağladığı avantajlar hakkında yetersiz bilgiye sahip olmalarıdır (Yavuz, 2010). Aynı zamanda taş ocağı işletmecisi, taşçı ve peyzaj mimarlarının koordineli bir çalışma yapmamaları da kullanım oranının artmasını engellemektedir. Tasarımcıların Urfa taşı hakkında bilgi sahibi olmaları ile hangi tür tasarımlarda Urfa taşının kullanılacağını tespit edebilirler. Urfa taşının çıkarılması, üretimi ve nakliyesinde, çevresel sürdürülebilirliğin sağlanması için iyileştirici önlemlerin alınması gerekmektedir. Tasarımcıların, yaptıkları tasarımlarda yerel malzeme olan Urfa taşının seçimine ağırlık vermesi; istihdam olanağı ve yerel ekonomiye katkı sağlayacak, döviz harcamalarını azaltacaktır. Yerel malzemelerin güncel tasarımlarda yeniden yorumlanması, mimari çevrede kültürel sürekliliğge olumlu katkısı olacak, kentin yaşam kültürü ve geçmişini simgeleyen doğal taşların kullanımı mevcut alanları daha kimlikli yapacaktır.

Urfa taşının peyzaj düzenlemeleri ve bunun yanında kent mobilyaları yapım malzemesi olarak kullanılması ile tasarımlar daha da zenginleşecek doğal kaynakların kullanımı sağlanacaktır. Günümüzde taş ustalarının sayısının azalması, yeni neslin taş ustacılığı mesleğinin zorluğundan dolayı taş işlemeciliği önemini kaybetmektedir. Bu kapsamda yerel yönetimler ve Millî Eğitim Bakanlığı'nın desteği ile taş işlemeciliği ile ilgili eğitimlere ağırlık verilmelidir. Taş işlemeciliğinde bilgisayar kontrollü makinaların (CNC) kullanımı ile taşın işlenmesi kolaylaşacak, seri üretimle daha fazla mimari ögede taşın kullanımı sağlanmış olacaktır. 


\section{Kaynaklar}

1. Ăgan, C. (2016). Geleneksel Yapı Malzemesi Olarak Şanlıurfa Kireçtaşlarının Koruma ve Cilalama Performansı Üzerine Bir Ön Çalışma. Mühendislik Jeolojisi ve Çevre Bülteni, 75 (1), 13-25.

2. Akgün, A., Evci Kiraz, E.D. (2019). Sürdürülebilirlik Kavramı, Çevresel Etki Değerlendirme ve Stratejik Yaklaşım. $\quad$ https://www.skb.gov.tr/surdurulebilirlik-kavrami-cevresel-etki-degerlendirme-ve-stratejikyaklasim-s31772k/ (17.06.2021).

3. Aksoy, A. Ö. (2020). Sürdürülebilir Bir Bakış Açısı ile Doğal Taşın Kullanımı. http://www.naturadergi.com/anasayfa/surdurulebilir-bir-bakis-acisi-ile-dogal-tasinkullanimi/?fbclid=IwAR1el2Rd8I3aVxcXxZcjGqTGKLsJcIkcmVuvtJg-HpbvcKcp4g9tXirI2-Q (17.06.2021)

4. Albayrak, Y. (2015). Soğmatar Kült Merkezi ile İlgili Yeni Öneriler. Belgü, 2, 253-268.

5. Alkan, A. (2015). Bitlis Şehrinde Taş Ustalığı ve Geleneksel Kent Mimarisine Etkisi. Turkish Studies International Periodical For The Languages, Literature and History of Turkish or Turkic Volume 10/6 Spring 2015, p. 57-82

6. Alptekin, G. (2021). Sürdürülebilirlik Bağlamında Marmara Mermeri ve Güncel Tasarım Örnekleri. Online Journal of Art and Design, 9(4).

7. Altınçekiç, H. (2001). Bazı Doğal Taşların İrdelenmesi ve Peyzaj Düzenlemelerinde Kullanım Olanakları. İstanbul Üniversitesi Orman Fakültesi Dergisi, 51(1), 49-58.

8. Anonim (2019a). Şanlıurfa Ticaret Odası 2019 verileri

9. Anonim (2019 b). https://www.sanliurfa.bel.tr/icerik/68/6/inanc-turizmi, Stratejik Plan1, (17.06.2021).

10. Anonim (2020). http://www.ruhatasi.com/haber-detay, (17.06.2021).

11. Anonim (2021). https://www.spotblue.com, (17.06.2021).

12. Erdönmez, M.Ö., Çetingöz U. (2019). İstanbul'un Bazı Heykel ve Plastik Objeleri https://www.plantdergisi.com/dr-ipek-muge-ozguc-erdonmez-peyzaj-mimari-ulas cetingoz/istanbul-unbazi-heykel-ve-plastik-objeleri.html (17.06.2021)

13. Farrelly, L., (2011). Mimarlığın Temelleri (Çev. Neslihan Şık). Literatür Yayınları, Akademik Temeller Dizisi 01, İstanbul.

14. Güner, E. (2015). Kent Kimliği İlişkisi Bağlamında Kent Mobilyaları: Sultanahmet Meydanı Örneği, Yüksek Lisans Tezi, Arel Ün. Fen Bilimleri Enstitüsü, İstanbul.

15. Güremen, L. (2011). Kent Kimliği Ve Estetiği Yönüyle Kentsel Donatı Elemanlarının Amasya Kenti Özelinde Araştırılması. Social Sciences. 6(2), 254-291.

16. Huber, J., (2006). Landscaping With Stone, Sunset Homeowner, Oxmoor House, California.

17. Işık, N. (2007). Geleneksel Yapılardaki Taş Malzemenin Fiziksel Kullanım Alanları ve Özelliklerinin Belirlenmesi; Ahlat Taşı Ve Diyarbakır Karacadağ Bazaltı Karşılaştırma Örneği.

18. Kazancı, N., Gürbüz, A. (2014). Jeolojik Miras Nitelikli Türkiye Doğal Taşları. Türkiye Jeoloji Bülteni, 57(1), 19-44.

19. Kürkçüoğlu A.C. (2016). Göbeklitepe'den Günümüze Şanlıurfa Mimarisinde Taş Süsleme. Şanlıurfa Ticaret Odası. Şanlıurfa.

20. Kürkçüoğlu, S., Erkol, G. (2013). Şanlıurfa Kültür ve İnanç Turizm Potansiyelinin Değerlendirilmesi. Uluslararası Inanç Turizmi ve Hoşgörü Konferansı, Necmettin Erbakan Üniversitesi, Konya. 795-813.

21. MTA (2010). Maden Tetkik ve Arama Genel Müdürlüğü. Güneydoğu Anadolu Bölgesi Maden Envanteri,http://www.mta.gov.tr/v1.0/bolgeler/diyarbakir/index.php?id=gdab_maden_envanteri_maden\&m $=4,(28.01 .2010)$

22. Neufert, E. (1979). Neufert Yapı Tasarımı Temel Bilgileri, Güven Yayıncılık, İstanbul.

23. Özdemir, İ. (2005). Yapı Elemanları Ders Notları, T. C. Osmangazi Üniversitesi, Eskişehir.

24. Reed, D, (2000). The Art \& Craft of Stonescaping. Lark Books, U.S, 156 p.

25. Sağlık A., Kelkit A., Sağlık E. (2012). Peyzaj Mimarlığında Doğal Taş Kullanımı:Çanakkale Kenti Örneği", 8th International Marble and Natural Stone Congress, 763-770, 13-15 Aral1k 2012, Afyon.

26. Şişman, E. E.; Yetim, L. (2004). Tekirdağ Kentinde Donatı Elemanlarının Peyzaj Mimarlığı Açısından İrdelenmesi, Trakya Üniversitesi Fen Bilimleri Dergisi, 5(1), 43-51.

27. Uzun, G., (1990). Kentsel Rekreasyon Alan Planlaması, Çukurova Üniversitesi Ziraat Fakültesi, Ders Kitabı No: 48, Adana, $100 \mathrm{~s}$.

28. Turgut, P., Yeşilnacar, M.İ., ve Bulut, H. (2006). Yapı malzemesi olarak Urfa taşı'nın mekanik, fiziksel ve teknolojik özelliklerinin tespiti. TÜBİTAK-MAG, 104I084.

29. Yavuz, H. (2010). Doğal taş elemanlarının peyzaj düzenlemelerinde kullanımı Doktora Tezi, İstanbul Teknik Üniversitesi Fen Bilimleri Enstitüsü, Peyzaj Mimarlığı Anabilim Dalı, İstanbul. 